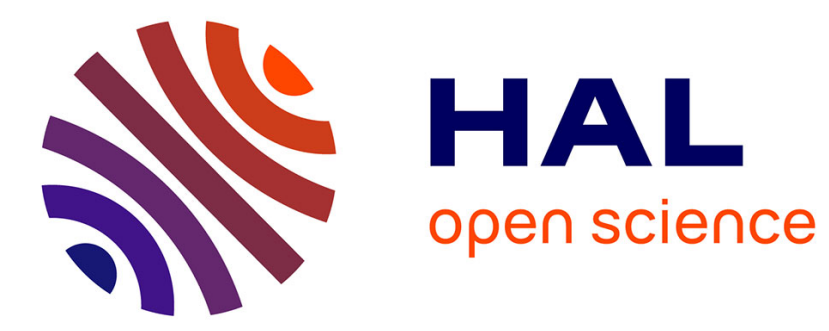

\title{
Partition, migration, and jute cultivation in India
}

James Fenske, Prashant Bharadwaj

\section{To cite this version:}

James Fenske, Prashant Bharadwaj. Partition, migration, and jute cultivation in India. The Journal of Development Studies, 2012, pp.1. 10.1080/00220388.2011.579114 . hal-00807096

\section{HAL Id: hal-00807096 https://hal.science/hal-00807096}

Submitted on 3 Apr 2013

HAL is a multi-disciplinary open access archive for the deposit and dissemination of scientific research documents, whether they are published or not. The documents may come from teaching and research institutions in France or abroad, or from public or private research centers.
L'archive ouverte pluridisciplinaire HAL, est destinée au dépôt et à la diffusion de documents scientifiques de niveau recherche, publiés ou non, émanant des établissements d'enseignement et de recherche français ou étrangers, des laboratoires publics ou privés. 


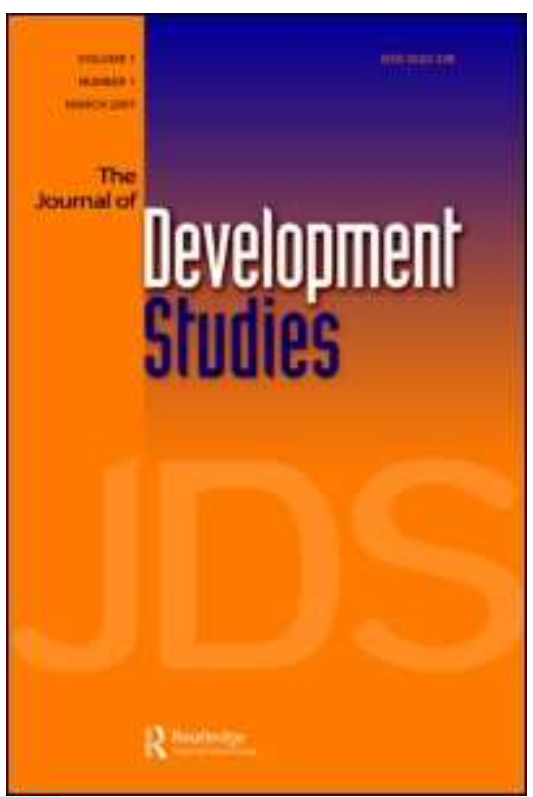

\section{Partition, migration, and jute cultivation in India}

\begin{tabular}{|r|l|}
\hline Journal: & Journal of Development Studies \\
\hline Manuscript ID: & FJDS-2010-May-0001.R2 \\
\hline Manuscript Type: & Original Manuscripts \\
\hline Keywords: & $\begin{array}{l}\text { Economic development < Economics, Agricultural development }< \\
\text { Economics, Migration < Employment and Law, South Asia < } \\
\text { Geographical Area, Borders < Human Geography, Trade }< \\
\text { Economics }\end{array}$ \\
\hline
\end{tabular}

\section{SCHOLARONE} Manuscripts 


\begin{abstract}
We show that refugees can play positive roles in receiving economies by looking at the partition of India. We use an instrumental variables (IV) strategy to show that migrants played a major part in India's take-up of jute cultivation. Our estimates suggest that migrants fully explain post-partition jute cultivation. Consistent with migrants bringing jute-specific skills with them, we find that migrants did not depress jute yields, did not increase the cultivation of other crops, and did not lower native wages. Our results are robust to migrant selection into districts with the best markets for jute.
\end{abstract}

\title{
1. Introduction
}

In March 2010, a disputed island in the Bay of Bengal disappeared beneath the rising sea. Global warming may soon swallow more islands in the Sundarbans region of Bangladesh (BBC News, 2010). Recent press accounts have described the struggles of migrants pushed by floods into Dhaka, speculating that thirty million Bangladeshis could be displaced by climate change (Harrabin, 2006; Kakissis, 2010). Environmental refugees apart, recent years have produced mass migrations due to ethnic and religious violence. These movements are important from a historical perspective, and understanding them will provide key insights as such events are likely to happen in the future. The war in Iraq has already generated millions of displaced people who have migrated en masse into neighboring countries. Nations such as Jordan and Syria now have some of the highest concentrations of refugees per capita in the world (FMR, 2007).

How are we to predict the effects of these mass migrations? Reuveny (2007) suggests that the best evidence will come from past experience. He notes that, since 1950, environmental problems have pushed an unknown number of Bangladeshi migrants into urban areas, half a million into the Chittagong Hill Tracts, and more than fifteen million into India. This has led to conflict, insurgency, and massacres. In this paper, we focus on another historical episode of mass migration in order to answer a more narrow question -- can economies that receive mass migrants absorb them and benefit from them? In particular, we study the impact of partition migrants on India's jute economy.

The partition of India, 1947-1951, pushed three million refugees into the eastern states of India and separated the jute fields of East Pakistan from Calcutta's jute mills, spurring demand for locally-grown jute. We use these twin shocks to investigate the ability of the Indian economy to assimilate these migrants. Because migrants may have selected into the districts that were most suitable for an expansion of jute production, we rely on an instrumental-variables approach to identify the impact of partition-related migration on jute production. We use a district's distance from the border at partition to predict migrant flows into a district. We find that the districts in Eastern India most affected by migrant flows were those that took up jute cultivation most extensively after partition, and that migrants did not depress yields in the districts in which they settled. Further, we find no evidence that migrants depressed local wages, or that expanded production harmed natives through a decline in the price of jute. Similar effects are not observed for other crops. These results suggest that migrants spurred jute cultivation because they brought specific skills with them, and not simply because they provided a greater supply of labor. 
The ability of the receiving economy to assimilate migrants is related in turn to three broader questions. First, what economic impact did partition have on India? Second, to what extent are migrants and refugees "good" or "bad" in general for the receiving economy? Third, can migration act as a substitute for trade?

The migration due to partition involved approximately 16 million people crossing borders in a span of 3 years (Bharadwaj et al., 2008b). The migration brought about demographic changes, altering sex ratios, occupational structures, and literacy rates in Pakistan and India (Bharadwaj et al., 2008a). Mortality due to the migration was high (Hill et al., 2006). However, little empirical work has been done on the economic impacts of partition. Vakil's Economic Consequences of a Divided India (1950) is one of the few contributions that has examined some of the economic implications of partition. However, his analysis uses data aggregated to the state level; we use finer, district-level data in our study. Moreover, his book was written before the census of 1951 and before detailed data on agricultural outcomes were collected, which we are able to use. Most of the work on partition has been qualitative; see Bharadwaj et al., 2008a. Our paper is one of the few to quantitatively analyze the impact the migratory flows after partition on specific economic outcomes.

Large-scale migrations are important and disruptive events. Studies have linked mass migration to many outcomes, including environmental degradation in China (Ta et al., 2006), convergence among OECD countries before 1913 (Taylor and Williamson, 2006), and state security in the interwar period (Rudolph, 2003). During the nineteenth and early twentieth centuries, millions of European immigrants came to the United States, and their arrival shaped, among other effects, the growth of wage inequality (Margo and Villaor, 1987), the composition of imports (Dunlevy and Hutchinson, 1999), and the timing of black migration out of the South (Collins, 1997). Other studies have stressed the capacity of receiving economies to absorb migrants, showing that they have only minor impacts on native labor market outcomes in the US (Altonji and Card, 1991; Borjas, 1991; Goldin, 1994; Grossman, 1982) and Israel (Friedberg, 2001).

Most of this literature has concentrated on voluntary migrations. Studies that examine involuntary migrations tend to focus on the resulting trauma and human hardship, without addressing how receiving economies may be able to absorb these refugees or might benefit from an increase in the supply of labor and skills. During an involuntary migration, the composition of migrants is different. If most members of a particular religious or ethnic group leave from the sending country, the same pattern of skill selection may not occur as under a voluntary migration (Borjas, 1987; Chiquiar and Hanson, 2005). In addition, it is not clear that the occupational choices made by forced migrants will be responsive to market signals in the receiving country. Our results suggest that a sudden increase in labor supply can make markets more responsive to a change in the price of a labor-intensive product. We suggest that migrants can play a positive economic role even at a time of crisis. We do not, however, undertake a full general equilibrium analysis -- instead we look at the impact of migrants on jute production, other crops, and a handful of outcomes for natives that we are able to measure.

Samuelson's "factor price equalization" result makes trade a substitute for migration; wages are made equal across countries that can trade, even if labor cannot move. The reverse may also be 
true -- countries that cannot trade may achieve specialization through labor migration. Theoretical and empirical results on this question have been mixed, and have focused on whether trade encourages migration or vice versa. López and Schiff (1998) argue that trade and migration are complements, since liberalization may spur out-migration of unskilled workers. Wong (1986) concludes that, ultimately, the result will depend on factor endowments, technology, and preferences. In a case more analogous to forced migration, Ethier (1985) suggests that 'captive' migrants unable to return to their home countries reduce the sensitivity of output and prices to changes in international demand. The impact of migration will also depend on whether externalities exist from migration, and whether they can be internalized (e.g. Schiff (1996)).

Empirically, Dunlevy and Hutchinson (1999) find that trade and migration are complements, as immigrants purchase goods produced in their home countries. Collins et al. (1997), similarly, find that during the first wave of globalization, the substitutability of trade and migration can be soundly rejected. Bruder (2004), alternatively, finds that while migration into Germany does not affect the level of trade with migrants' home countries, increased trade reduces migration. We find that 'captive' migrants in Eastern India produced what they would have cultivated in their home country, substituting domestic production for the inter-regional trade that had existed in the absence of partition.

If we are to use India's experience with jute after partition to learn about present migrations, we must establish that future migrants will face similar opportunities. In particular, our results suggest that refugees from East Pakistan were able to find land for cultivating jute. Recent work on Bangladesh, however, has suggested that land scarcity is a major issue that has changed land use and given rise to violent conflict (e.g. Homer-Dixon (1994), Turner and Ali (1996)). Also crucial to our story is a healthy market for cash crops in which migrants could participate. Jute products remain a major category of Bangladeshi trade, but this market has declined with the spread of synthetic packing materials. Garments, leather and fish products are now important exports. Inland fisheries rely heavily on seasonal unskilled labor, much of which is currently provided by poor segments of local communities (The World Bank, 2006). Our results suggest that whether migrants are able to participate in these industries and whether they possess skills in them will determine their economic assimilation. Also critical to our findings is that the role of technology in raising jute yields does not interact with migrant arrival; if increased yields depend on technological change, migrants' effects on wages will depend on the degree of labor market segmentation.

The remainder of this paper proceeds as follows. Section 2 provides background on the jute industry in Bengal. Section 3 explains the empirical strategy and describes the data used for the study. Section 4 presents the empirical results. Section 5 shows that our results are not found for other crops, and are robust to migrant selection. Section 6 concludes.

\section{Background: Jute in India and the partition}

Jute, the "golden fibre," dominated the economic life of Bengal from the mid-nineteenth to the mid-twentieth centuries (Sen, 1999, p. 13). Raw and manufactured jute products taken together were India's $5^{\text {th }}$ largest export in 1878 , and by 1921 they were $1^{\text {st }}$, forming more than a quarter of India's exports (Stewart, 1998, p. 12). Though the jute industry suffered during the 1930s, by 
1940 Indian jute mills possessed 68,415 looms -- 57\% of the world total (Stewart, 1998, p. 16). The industry employed approximately 300,000 people in 1940; since most of the mills were concentrated in Calcutta, this meant that close to $15 \%$ of the population of Calcutta worked in jute (van der Steen, 2005). Bengal held a near-monopoly on world jute cultivation, a position due largely to its combination of sandy loam, favorable rainfall, hot and humid climate, and access to rivulets (Sen, 1999, p. 13). Finally, jute was also labor-intensive, requiring ploughing, weeding during its early stages of growth, harvesting by hand, and retting (Stewart, 1998, p. 28). Since jute is a labor-intensive crop, Bengal's abundant population may have given it an additional advantage.

Partition "placed an artificial barrier between the jute-growing eastern districts and the jute mills that had come up in the west around Calcutta" (Bose, 1993, p. 44). 81\% of existing jute cultivation was in what became East Pakistan, while all of the mills were in West Bengal (Ghosh, 1999, p. 63). East Pakistan imposed export duties on raw jute, and selectively reduced the quality of jute shipped to India (Ghosh, 1999, p. 63). The twin results were a sharp decline in the supply of raw jute to Indian mills, and a subsequent increase in the price of raw jute. In Figure 1, it is clear that the price increases brought on by the Second World War were not reversed after 1945. Data here and in Figure 2 are taken from IJMA (1963). Indeed, the price of loose jute continued to rise until 1950, and remained well above its historical average afterwards. Figure 2 presents evidence of the rise in Indian jute cultivation that resulted from partition, reporting the total hectares planted to jute and the production of jute in West Bengal and East Pakistan, each indexed to their 1947-48 values. A temporary spike coinciding with the beginning of the Second World War is apparent. While it is clear that jute production expands rapidly in West Bengal after partition, no similar break appears for East Pakistan.

Because of restrictions on trade between the two new countries, the increased price due to demand from mills in West Bengal affected only the Indian districts that could cultivate jute. partition induced a clear supply response from the Indian countryside, but not from East Pakistan. In the latter, the market for jute production was sustained by the development of mills centered in Narayanganj. These included the Adamjee Jute Mill, established in 1951, which became the largest jute mill in the world. These mills were nationalized after Bangladesh achieved independence in 1971. Cultivators in Bangladesh continued to plant jute alongside rice. Though three trade agreements were concluded with East Pakistan between 1950 and 1953, mills in West Bengal sought raw jute from the Indian countryside, and by 1958 domestic production had expanded to supply almost the entire raw material needs of the Indian mills (Ghosh, 1999, p. 64). The goal of this paper is to show the extent to which migrants contributed to the Indian uptake.

One of the main features of the migratory flows during partition was their unevenness across the two borders. While fairly equal numbers of people moved between West Pakistan and Indian Punjab, approximately 3 million migrants came into Bengal and its surrounding states, while only 600,000 migrants left India to enter East Pakistan (Bharadwaj et al., 2008b). Hence, along with a split between jute mills and fields, the partition resulted in net positive migration into West Bengal and states like Bihar and Orissa. Nearly $8 \%$ of West Bengal's population was composed of migrants in 1951. There was considerable variation across districts. Migrants were 
37\% of the population in Nadia in 1951 and 16\% in West Dinajpur, while in districts like Purnea and Hazaribagh, this figure was less than $1 \%$.

In a mere 9 years after partition, we find that districts with more migrants were the predominant suppliers of jute to the mills in Calcutta. However, the mechanisms by which migrants affect jute outcomes (acreage, output and yield) are difficult to disentangle, and cannot be conclusively addressed with the data we have. For example, if the government focused on areas with more migrants and gave them subsidies for growing jute, then we cannot distinguish this from a story in which migrants brought in jute-specific experience. Moreover, we cannot directly test whether migrants worked the jute fields as such detailed occupation data is not available from this time period. However, the findings that many other crops did not see an increase in acreage during this period and that jute yields increased in areas with more migrants are suggestive of the effect of jute-specific skills.

To our knowledge, the literature has given no attention to any role that may have been played by migrants in facilitating jute production; our study adds a new hypothesis to the study of partition. Though peasants made up three quarters of East Bengal's Hindus, they provided only $40 \%$ of its refugees (Chatterji, 2007, p. 118). Few left before communal violence broke out in 1949. Most went to three districts -- 24 Paraganas, Calcutta and Nadia -- and the rest settled largely in West Dinajpur, Cooch Behar and Jalpaiguri. Those who were peasants "tended to cluster in agrarian, or semi-agrarian, tracts along the border between the two Bengals" in areas with poorly drained soils that were formerly areas of out-migration (Chatterji, 2007, p. 122-123). Kin networks helped the refugees to settle and to buy or rent land (Chatterji, 2007, p. 115). Often, their holdings were too small or scattered to make a living, and many drifted to urban centers (Chatterji, 2007, p. 125). Chatterjee (1997) attributes the greatest influence of partition migrants on agrarian relations in West Bengal not to cultivators, but to urban refugees, who served as "the most organized and articulate section of the population and as the vanguard of organized political movements in the state [as it] acquired new tones of radicalism." By focusing on the role of migrants in agriculture, we help to fill a gap in the literature, while highlighting a positive contribution made by these refugees to the Indian economy.

\subsection{Empirical Strategy}

\section{Data and Empirical Strategy}

Since we relate migrant presence to jute expansion in a district, reduced-form estimates of the impact of migration on jute cultivation will be biased by migrant selection into districts whose unobserved characteristics may be correlated with their suitability for expansion of jute cultivation. We rely on an instrumental-variables approach that uses the logarithm of a district's distance from the border to predict the square root of migrant flows into a district. We use the square root of the migrant share of the population because visual inspection of the data suggests that the relationship is concave. Since some districts received either few migrants or none at all, the square root is a more appropriate transformation than the natural log. The idea behind this instrument is that the distance migrants had to travel from East Pakistan imposed costs on them that entered into their location decisions, and were uncorrelated (conditional on other controls) with the suitability of these districts for the future cultivation of jute. 
A simple empirical specification that allows us to examine the impact of partition-related migration on jute production is:

$$
\begin{gathered}
Y_{i}=\beta M_{i}+X_{i}^{x} \gamma+\epsilon_{i}, \\
M_{i}=\lambda D_{i}+X_{i}^{s} \alpha+\varepsilon_{i} .
\end{gathered}
$$

Here, $Y_{i}$ is jute acreage per capita in district $\mathrm{i}$ in 1956. $M_{i}$ is the square root of the share of migrants in that district in 1956. $X_{i}$ is a set of controls that includes (among other variables) jute production in 1931, population density in 1956, literacy rates, the share of minorities in the population in 1931, and state fixed effects. As is mentioned above, the problem with estimating (1) on its own is that factors in $\epsilon_{i}$ matter for both outcomes $Y_{i}$, as well as migration $M_{i}$. OLS estimates of $\beta$, the effect of migration on output, will be biased. One way of tackling this identification problem is to use instrumental variables. Essentially, we need to find variables that predict migration, but are not correlated with the elements of $\epsilon_{i}$.

We use $\log$ distance $D_{i}$ to the eastern border as the excluded instrument from the second stage regressions. For this specification to be valid, $D_{i}$ must predict $M_{i}$ and must also be uncorrelated with $\epsilon_{i}$, the unobserved determinants of jute cultivation. In Bharadwaj et al. (2008b), the authors establish that partition related migration into district $i$ is strongly related to the distance of district $\mathrm{i}$ from the border. However, there are two reasons the exclusion restriction may fail. First, distance may induce selection in the types of migrants. Second, distance may be correlated with unobserved geographic factors that determine a district's suitability for growing jute.

The first type of problem is not a major concern here. Bharadwaj et al. (2008b) find that more literate migrants traveled further from the border. We are concerned, however, with the impact of largely illiterate and poor migrant peasants. If distance was a greater concern for them than for wealthier, literate migrants, our instrument will under-predict the impact of distance on the type of migration we care about, biasing our estimates of $\beta$ towards, rather than away from zero. In addition, the boundary decision was kept secret until independence was granted on August 15th, 1947 - hence, there was a "surprise" element to where the boundary was actually placed.

The second concern is more worrisome a priori, but our empirical results provide evidence in favor of our identification strategy. Our IV results are robust to the inclusion of other observable features of the districts in our sample. When state fixed effects are included to account for unobserved heterogeneity, the magnitude of our IV coefficient estimate rises, suggesting that if we were able to include the full vector of determinants of jute cultivation, the estimated impact of migration would grow larger, not smaller (Altonji et al, 2005). Moreover, the boundary decision was based on religious composition of the areas, as opposed to considerations for agricultural productivity, or as is important for our case, agricultural suitability for jute. We present additional robustness checks in Section 5.

Figures 3, 4 and 5 depict our empirical strategy in maps. Figure 3 plots district-level jute production per head in 1956; this is very clearly concentrated in the eastern districts of our sample, which Figure 4 shows are also those districts that received the most migrants. Figure 5 confirms that these are also the districts that are closest to the border. It is also clear from these figures that agricultural data are unavailable for Assam, Manipur or Tripura. Our source for post- 
partition agricultural data, the India Agriculture and Climate Data, did not compile agricultural data for these states. Historically, it has been difficult to collect data from the Northeastern states in India for security reasons.

\subsection{Data}

This paper uses two major sources of data. For variables related to demographics and migration, we use data from the Censuses of India from 1931 and 1951. Demographers generally do not consider the 1941 census to be reliable, and so we use the 1931 census for pre-partition district characteristics. For the agricultural variables, we use the 1931 Agricultural Census and the World Bank Agricultural and Climate data set.

We use the Census data at the district level, since this is the lowest administrative unit at which demographic data is consistently available (the census data is not at the individual level - it is aggregated data at the district level). Further, it becomes nearly impossible to identify the same geographical units over time if lower administrative units such as tehsils are used. In order to create comparable units of analysis that take post-partition boundary changes into account, administrative maps are used from the two census periods to create a visual match. These are then validated by comparing census data on land area. These matches are described in more detail in Bharadwaj et al. (2008a). The most important variable for our purposes is the measure for migration. In our case, collecting this variable from the Censuses was made simple as the Censuses of 1951 in India and Pakistan directly ask about migrant status. Hence, migrant inflows were obtained directly from the 1951 census, since it asked respondents directly whether they had migrated during partition. The term used for such migrants is "displaced persons" in India, and "muhajir" in Pakistan. Neither measure captures internal migration, so these provide a good estimate of the number of people who moved due to partition on either side. This question was not asked in the 1961 census, hence, we can only obtain reliable estimates of migration due to partition from the 1951 census.

The Agricultural Census of India, 1931, provides district level data on acreage and yields of various crops. We match this district level data to the Census data in 1931 and subsequently to data from 1951. We use the India Agriculture and Climate data set for post-partition agricultural data. The India Agriculture and Climate data does not contain district level agricultural information for 1951, but it does contain district level data starting in 1956. Unfortunately the agricultural data is not at available at the tehsil level. This data set also has information on acreage and yield of various crops. Hence, we use 1956 as our post-partition data on agriculture. Jute output is an imputed variable, calculated by multiplying acreage by the estimated yield. Summary statistics for the data used in our empirical analyses are presented in Table 1.

\section{Results}

\subsection{Did migrants impact acreage and production?}

Table 2 presents OLS and IV estimates (3) for districts in the eastern Indian states of Bihar, West Bengal and Orissa. These are the states that predominantly received partition migrants, and are those that mostly cultivated jute. In column (1) of Table 2, we project acres of jute per capita on 
our measure of migration and a constant. Column (1) reveals a positive and statistically significant correlation between migration and jute cultivation. First stage results are reported in Table 8.

Column (2) adds additional controls. These are: the acreage planted to jute in 1931, population density in 1956, a dummy for the presence of a big city in the district, male literacy in 1956, the share of minorities in 1931, and a dummy for Nadia district. Jute acreage in 1931 is intended to control for three possibly competing factors -- a conditional convergence effect whereby districts with low initial acreages might grow more quickly, an experience effect whereby states with high initial acreages may find further expansion into jute more profitable, and unobserved longrun determinants of jute suitability. Male literacy proxies for the stock of human capital, and helps disentangle the separate effects of skilled and unskilled migrants. This will unfortunately be only a rough proxy for human capital, since it is a rate, and does not measure the actual level of education or literacy. The big city dummy captures demand factors that alter the orientation of agriculture. The minority ratio in 1931 controls for the long-run effects of prior occupational differences between Muslims and Hindus within agriculture. Visually, Nadia appears to be an outlier with the highest migration rate in the sample, but relatively low levels of jute production. Excluding Nadia from the analysis does not substantially alter our results. However, since the sample size is already small, we instead choose to include Nadia, and use a dummy variable to capture the (potentially non-linear) effects of the high migration rates into this district.

We find that the impact of partition migrants on jute cultivation is robust to the inclusion of these additional controls. Jute acreage in 1931 positively predicts cultivation in 1956, suggesting that it captures either unobserved suitability or the effects of accumulated experience with that crop over time. Population density negatively predicts jute cultivation. This is surprising, since it is a crop well suited to labor abundance. This may also be capturing the effect of smaller urban centers that are not captured by our "big city" dummy, or substitution into even more laborintensive crops in these districts. The minority share in 1931 is a strong positive predictor of jute cultivation. Areas with more minorities in 1931 saw greater out-migration as a result of partition. That this is positively correlated with jute cultivation suggests that, as migrants left, their farms became available for planting to other crops. As confirmed by visual inspection, Nadia is an outlier with cultivation far below the regression line. We find no effect of either the big city dummy, or of male literacy.

Column (3) adds the state fixed effects to control for unobserved state-level heterogeneity. The estimated effect of migration is insignificant in this specification, but since the coefficient has grown larger and the t-statistic is still 1.53, this is most likely due to multi-collinearity. The estimated coefficients on the other controls remain mostly stable, though the effect of population density falls and becomes insignificant. Column (4) adds the acreages of the other crops available in the data in 1931 - wheat, rice, sugar, maize, groundnut, barley, tobacco, gram, ragi, sesamum, rape, bajra, cotton and jowar. These are meant to control for similar, though competing effects as the 1931 acreage of jute. Unfortunately, the degrees of freedom in this regression are few, and so the results must be viewed with caution. The estimated effects of migration, minority share in 1931, and the Nadia dummy remain stable and significant, but the coefficients on 1931 jute acreage, the big city dummy, and population density all change sign. The magnitude of the effect of migration is substantial. The OLS estimates in columns (1) 
through (4) suggest that a one standard deviation increase in the square root of migrant share increases the acreage planted to jute by between 0.42 and 0.59 standard deviations. The average increase of 1.19 in our migration measure predicts between a 1.38 and 1.92 unit increase in our normalized measure of jute acreage per capita -- $63 \%$ to $87 \%$ of the average (2.20).

Columns (1) through (4) are replicated using our instrumental-variables approach in columns (5) through (8). In all four columns we find that the causal impact of migrants on jute cultivation is robust to this approach for removing locational selection by migrants. The fact that the IV estimates are larger suggests that migrants selected into districts that were less disposed to jute cultivation, making their decisions along dimensions negatively correlated with suitability for jute. Alternatively, this change may be due to mis-measurement of migrant flows. These are likely captured with error, which will bias the OLS coefficients towards zero. Physical distance is more precisely measured, and the IV approach may be helping to overcome this attenuation bias. Again, the magnitude of these impacts is of reasonable economic significance; across columns, the results suggest a one standard deviation increase in our migration measure produced between a 0.47 and 0.83 standard deviation increase in jute acreage. Following the same logic as above, our IV results suggest that on average migrants can explain between $70 \%$ and $122 \%$ of average jute acreage per capita. Estimates on the impacts of the other controls are very similar in the IV specifications as in the OLS.

We have replicated these tests with an alternative measure of jute expansion -- physical output. This measure is imputed by multiplying reported acres by reported yield. The results are consistent in terms of signs and significances with those of Table 2; these are not reported, but are available on request.

\subsection{Skills versus labor supply.}

The data we have cannot conclusively tease out the mechanism by which migrants drove an increase in jute output. We argue here that migrants also drove an increase in yields, and that this is consistent with these migrants having skills specific to jute cultivation. What this rules out is a story of raw labor supply, in which migrants expanded the cultivation only onto marginal lands less suitable for jute. While it is also possible that increased labor on a fixed amount of land can produce greater yields per acre, we find that migrants increase yields even conditional on population density. What we cannot rule out is that government services and agricultural technologies were more available in districts that received more migrants as a consequence of their arrival.

Table 3 investigates whether the impact of migrants worked through an improvement of jute yields. The ordering of columns here mirrors Table 2 in its inclusion of covariates and state fixed effects. Both the OLS and the IV estimates suggest that migrants in fact raised jute yields in the districts to which they migrated. The economic importance of these effects is not as precisely estimated as for output. Across OLS columns, a one standard deviation increase in our migration measure predicts an increase in yields between 0.22 and 0.50 standard deviations; in the IV, the comparable range is 0.33 to 0.94 . 
Several of the other coefficients also enter significantly. Jute acres in 1931 positively predict later yields, furthering the conclusion that this variable is capturing either a district's intrinsic suitability for jute cultivation or its accumulated experience with the crop. Population density positively predicts yields, consistent with an increase in the labor intensity of agricultural production in all types of agriculture in the most densely settled areas. The big city dummy, surprisingly, has a negative effect on yields. This may be due to negative externalities from these centers, greater labor costs in these districts, or to an orientation towards food production near urban markets. Male literacy has no impact on yields. In the pre-green revolution era, in which education was less important for farm management than today, this should not be surprising. The share of minorities in 1931 negatively predicts later yields. Since these districts saw greater outmigration, this may be serving as a proxy for the degree of disruption during partition. In addition, minorities that remained behind after partition may have had access to worse land, on average. The large negative coefficient on yields for Nadia gives one reason why it is such an outlier in the previous tables; while the district received many migrants, it was less suited to jute cultivation than its observables would otherwise suggest, and so migrants were less likely to adopt jute conditional on arriving there.

\subsection{How did migrants affect native outcomes?}

While the above analysis shows that migrants from Bangladesh increased jute acreage and output in India, this does not immediately imply these migrants were a net benefit to the Indian population. For example, an increase in jute output may have harmed Indian farmers by depressing prices. There are outcomes in the agricultural census data that allow us to test for possible channels through which these migrants may have harmed native Indians. In Table 4, we replicate the analysis of Tables 2 and 3, using these outcomes as dependent variables.

The first outcome we examine is the price of raw jute. Contrary to the suggestion that extra output depressed prices, both the OLS and IV results suggest that, if migrants had any impact at all on jute prices, the effect was positive rather than negative. Second, we test whether the increased supply of labor depressed agricultural wages. Again, we find no evidence for this view. The OLS results suggest that wages were higher in regions that received more migrants. Clearly, these results could be due to endogeneity -- migrants will, all else equal, prefer districts with higher wages or where the jute they produce can be sold for more. The IV results show, however, that even controlling for this possible reverse causation there is a positive association between migration, prices, and wages.

Where migrants do appear to have affected natives in the census data is in the composition of the labor force. There is information available for these measures in a greater number of districts than for the other variables. Restricting the sample to that used in the other estimations does not change the sign or significance of any of the estimated coefficients. In districts that received more migrants, the share of the native-born population engaged in agriculture was lower. In addition, the share of the total population engaged in agriculture fell most dramatically (or grew most slowly) between 1931 and 1951 in districts that received more migrants. We are hesitant to infer a causal impact from these results. First, when state fixed effects are included in the regressions, these effects disappear. Second, these measures are coarse. They are divided even further into 8 categories; agriculture on owned lands, agriculture on un-owned lands, cultivating 
laborers, land-owners, non-agricultural production, commerce, transport, and "miscellaneous." We tested for similar results using these categories (not reported), and found a positive effect of migrants on agriculture on un-owned lands and a negative effect on cultivating labor.

In sum, there is no evidence that migrants from East Pakistan harmed Indian farmers by depressing wages or the price of jute. There may have been a crowding out effect, in which districts that received more migrants saw a drop in the share of both the native-born and total populations devoted to agriculture, but the statistical evidence for this is weak.

\section{Robustness}

\subsection{Placebo tests: Did migrants increase the cultivation of other crops?}

We have argued so far that we have recovered a causal impact of partition-related migration on jute cultivation, and that this has been driven by the skills that migrants carried with them. As a falsification exercise, then, we should be able to show that the impact of migration existed only for jute, because of its increasing importance after partition and its prevalence in the districts that sent migrants into eastern India. Table 5 looks at whether this story can be told for crops other than jute, and replicates column (7) of Table 2 for the other crops in the data. With the exception of rapeseed, these results are either insignificant or negative, suggesting that the relationship between jute expansion and migration in a jute-growing region is not a statistical artifact. This table also builds more evidence towards a jute specific skill story (as opposed to just a net labor supply story) as another very labor intensive crop - rice, does not see an increase in acreage. In addition, we use the acreage planted to all other crops as an outcome. This yields a point estimate of -1.24 with a standard error of 14.55. While the magnitude is similar to that of the impact on jute, which suggests that much of the expansion of jute came at the expense of other crops, this must be taken as suggestive due to lack of precision. In the bottom half of Table 5 we repeat this exercise using the yields of other crops as outcomes. Again, we find few significant impacts; the only other crop whose yield appears to have been positively affected by migration was tobacco.

\subsection{Migrant selection}

One threat to the validity of our instrumental variables strategy is that migrants may have selected into districts where the market for jute output was particularly favorable, and that this is correlated with distance from the border. The large city dummy we include in our main specification should already mitigate this concern, since a large majority of jute mills were (and still are) located near Calcutta (Fernandes 1997). Ease of shipping from the nearby ports, access to raw jute and the fact that the first jute mill in India was established there set up Calcutta as the center for jute mills in the country. As other sources note “... the jute industry in India enjoyed even more remarkable expansion, rising to commanding leadership by 1939 with a total of 68,377 looms, concentrated mainly on the River Hooghly near Calcutta. These mills alone have proved able to supply the world demand." (History of Jute, worldjute.com) If demand shocks were concentrated in those districts most suitable for growing jute, then we have already controlled for these in the main specifications by including the acreage planted to jute in 1931. 
We further demonstrate the robustness of our result to this potential problem in the first panel of Table 6. We add two new variables to our regression that directly capture the quality of the local jute market -- the price of raw jute, and the distance from Calcutta, the principal market for jute. This latter variable is normalized so that the most remote district in our data, Lakhimpur, has a distance value of 1 . Price unsurprisingly has a positive and marginally significant effect on jute acreage. Distance from Calcutta enters positively, given that it was northern districts such as Purnea that cultivated jute most intensively. Critically, our results for migration are robust to the inclusion of these additional controls. In many columns, adding these proxies for market quality does not reduce our coefficient estimates by much; this suggests that, were we to add a perfect measure of market quality, it would still not explain away our main results. Results with yields as an outcome are similar.

In the second panel, we take an alternative approach and include yields as a right hand side control. While these are potentially endogenous, if the entire impact of migration can be attributed to selective migration into districts suitable for jute, there should be no estimated effect of migration on acreage conditional on yield. It is clear from Table 6 that this is not the case. Finally, in the third panel, we regress acreage in 1956 on migration and on all available indicators of demand shocks or suitability for jute - lagged acreage, the big city dummy, average monthly temperature and rainfall in 1956, the price of jute, and distance from Calcutta. Rainfall and temperature data are not available for Howrah. The results in Column (1) suggest that lagged acreage is almost a sufficient statistic for these other controls, since only rainfall is significant when migration is not included. Even conditional on these, migration increases jute cultivation, in both the OLS and IV specifications.

\subsection{Sample size}

In general, small samples lead to imprecise estimates of the coefficient of interest. However, as we have seen, the coefficient of interest is significant in many specifications even with the small sample size. The other issue that often arises with small samples is selectivity. This is less of a concern in our case because the major jute growing region and the area affected most by migratory movement in the East were the same. Nevertheless, in the top panel of Table 7 we show that our results are robust to this concern. We replicate the analysis of Table 2 using all Indian districts in which jute acreage in 1956 was greater than zero. This doubles our sample size, and the significance and magnitude of our estimates of $\beta$ are very similar to those obtained in our more restricted main sample. We prefer our estimates from Table 2, however, since the inclusion of additional observations from outside of eastern India that generally have low levels of both jute output and in-migration will unduly bias the results in favor of our hypothesis.

\subsection{Yield in non-cultivating districts}

In Table 3, we have followed the convention of the raw data, coding as zero the yield of jute in districts with in which acreage is also zero. This is justifiable insofar as farmers' decisions not to cultivate jute at all in a district can be taken to indicate that the district is completely unsuited to jute production. Coding these areas as a zero in 1931 also keeps these districts in the analysis were they to begin cultivating jute after migrants arrive by 1956. This is not ideal, however, since it is likely to understate yields in non-cultivating districts. We take two alternative 
approaches to these districts, and show that, while the finding that migrants increased yields is not statistically robust, we can find no evidence that migrants depressed yields, supporting our interpretation that migrants brought skills in addition to their raw labor. In the second panel of Table 7, we replace the zeroes for non-cultivating districts with state means. In the third panel of Table 7 we simply drop these districts altogether. Unless we include all lagged acreages in 1931, in which case our results are unreliable due to the few degrees of freedom, our coefficient estimates are always positive in both tables and remain significant or are close to significant in several columns. While smaller, our estimates are generally of a similar order of magnitude.

\section{Conclusion}

In this study, we have used agricultural census data to investigate the differential take-up of jute cultivation across districts within eastern India following partition. Using an instrumentalvariables strategy, we have shown that those districts that received migrants were better able to meet the demand from a milling industry whose supply chain had been suddenly disrupted. Though our results cannot conclusively show that experience is an important determinant of crop choice and of responsiveness, they are consistent with such an explanation. Migrants also did not lower jute yields, even conditioning on population density, and did not have similar effects on other crops; these findings further support an explanation grounded in migrant skills. There is no evidence that they harmed locals by depressing wages or jute prices. We have shown, then, that even at a time of massive involuntary migration, migrants can show responsiveness to market conditions.

These results tell us about the economic effects of the partition of India, the impact of migration on receiving economies, and the substitutability of trade and migration. We find that the migrations associated with partition caused massive exchanges of labor and skills, and that these altered output choices and productivity in post-partition India. Migrants here were able to assist India in responding to economic disruption, without depressing yields in jute. This suggests that they aided both flexibility of agricultural output and brought knowledge with them that they may have passed on to other cultivators. They produced a crop that had been previously adopted from abroad, allowing India's jute milling industry to persevere, substituting for the trade in raw jute that had predated partition. Taken as a whole, our results highlight a positive role played by partition's refugees in eastern India, one that has been largely overlooked.

Refugees create severe challenges for receiving economies. News accounts and academic studies focus on their struggles in urban slums, and on the possibility of violent conflict (e.g. Reuveny (2007)). Our results suggest that migrants and the economies that receive them are resilient. While this cannot justify the suffering of those who are forced to move, it is clear that these migrants are capable of making beneficial contributions where they arrive.

\section{References}

Altonji, J., Elder, T., and Taber, C. (2005). Selection on observable and unobservable variables: Assessing the effectiveness of Catholic schools. Journal of Political Economy, 113(1):151-184. 
Altonji, J. G. and Card, D. (1991). The effects of immigration on the labor market outcomes of less-skilled natives, pages 201-234. Immigration, trade and the labor market. University of Chicago Press, Chicago.

BBC News (2010). Disputed Bay of Bengal island 'vanishes' say scientists.

Bharadwaj, P., Khwaja, A., and Mian, A. (2008a). The big march: Migratory flows after the partition of India. Economic and Political Weekly, (43):39-49.

Bharadwaj, P., Khwaja, A., and Mian, A. (2008b). The partition of India: Demographic consequences. Working Paper.

Borjas, G. J. (1987). Self-selection and the earnings of immigrants. The American Economic Review, 77(4):531-553.

Borjas, G. J. (1991). Immigrants in the US labor market: 1940-80. The American Economic Review, 81(2):287-291.

Bose, S. (1993). Peasant Labour and Colonial Capital: Rural Bengal Since 1770. Cambridge University Press, Cambridge.

Bruder, J. (2004). Are trade and migration substitutes or complements? The case of Germany, 1970-1998. Working Paper.

Chatterjee, P. (1997). The Present History of West Bengal: Essays in Political Criticism. Oxford University Press.

Chatterji, J. (2007). The Spoils of Partition: Bengal and India, 1947-1967. Cambridge University Press.

Chiquiar, D. and Hanson, G. H. (2005). International migration, self-selection, and the distribution of wages: Evidence from Mexico and the United States. Journal of Political Economy, 113(2):239-281.

Collins, W. J. (1997). When the tide turned: Immigration and the delay of the great black migration. The Journal of Economic History, 57(3):607-632.

Collins, W. J., O'Rourke, K. H., and Williamson, J. G. (1997). Were trade and factor mobility substitutes in history? NBER Working Paper No. W6059.

Dunlevy, J. A. and Hutchinson, W. K. (1999). The impact of immigration on American import trade in the late nineteenth and early twentieth centuries. Journal of Economic History, 59(4):1043-1062.

Ethier, W. J. (1985). International trade and labor migration. The American Economic Review, 75(4):691-707. 
Fernandes, L. (1997). Producing Workers: The Politics of Gender, Class and Culture in the Calcutta Jute Mills. University of Pennsylvania Press.

FMR (2007). Special issue: Iraqs displacement crisis: the search for solutions. Forced Migration Review, (June).

Friedberg, R. M. (2001). The impact of mass migration on the Israeli labor market. Quarterly Journal of Economics, 116(4):1373-1408.

Ghosh, T. (1999). Income and Productivity in the Jute Industry Across the 1947 Divide, pages 54-81. Case for labour history: the jute industry in Eastern India. K.P. Bagchi and Co, Calcutta.

Goldin, C. (1994). The Political Economy of Immigration Restriction in the United States, 1890 to 1921, pages 223-258. The Regulated Economy: A Historical Approach to Political Economy. University of Chicago Press.

Grossman, J. B. (1982). The substitutability of natives and immigrants in production. The review of economics and statistics, 64(4):596-603.

Harrabin, R. (2006). Climate fears for Bangladesh's future.

Hill, K., Seltzer, W., Leaning, J., Malik, S. J., and Russell, S. S. (2006). The demographic impact of partition: Bengal in 1947. Working Paper.

Homer-Dixon, T. F. (1994). Environmental scarcities and violent conflict: evidence from cases. International Security, 19(1):5-40.

IJMA (1963). Annual summary of jute and gunny statistics. Indian Jute Mills Association, Calcutta.

Kakissis, J. (2010). Environmental refugees unable to return home. New York Times.

López, R. and Schiff, M. (1998). Migration and the skill composition of the labour force: The impact of trade liberalization in LDCs. The Canadian Journal of Economics, 31(2):318-336.

Margo, R. A. and Villaflor, G. C. (1987). The growth of wages in antebellum America: New evidence. Journal of Economic History, 47(4):873-895.

Reuveny, R. (2007). Climate change-induced migration and violent conflict. Political Geography, 26(6):656-673.

Rudolph, C. (2003). Security and the political economy of international migration. American Political Science Review, 97(4):603-620. 
Schiff, M. (1996). South-north migration and trade: a survey. Policy Research Working Paper Series.

Sen, S. (1999). Women and Labour in Late Colonial India: The Bengal Jute Industry. Cambridge University Press.

Stewart, G. T. (1998). Jute and Empire: The Calcutta Jute Wallahs and the Landscapes of Empire. Manchester University Press.

Ta, W., Dong, Z., and Sanzhi, C. (2006). Effect of the 1950s large-scale migration for land reclamation on spring dust storms in northwest China. Atmospheric Environment, 40(30):58155823.

Taylor, A. M. and Williamson, J. G. (2006). Convergence in the age of mass migration. European Review of Economic History, 1(1):27-63.

The World Bank (2006). Bangladesh Country Environmental Analysis: Bangladesh Development Series Paper No: 12. The World Bank OCE, Dhaka.

Turner, B. L. and Ali, A. M. S. (1996). Induced intensification: Agricultural change in Bangladesh with implications for Malthus and Boserup. Proceedings of the National Academy of Sciences of the United States of America, 93(25):14984-14991.

Vakil, C. N. (1950). Economic consequences of divided India: a study of the economy of India and Pakistan. Vora, Mumbai.

van der Steen, B. (2005). The jute industry: A statistical overview. Working Paper.

Wong, K. (1986). Are international trade and factor mobility substitutes? Journal of International Economics, 21(1-2):25-43.

worldjute.com History of Jute available at http://www.worldjute.com/about_jute/juthist.html, As downloaded on January $8^{\text {th }}, 2011$. 


1
2
3
4
5
6
7
8
9
10
11
12
13
14
15
16
17
18
19
20
21
22
23
24
25
26
27
28
29
30
31
32
33
34
35
36
37
38
39
40
41
42
43
40
45
49
50
51
52
53
55
50

Figures

Figure 1. The price of raw jute in Calcutta

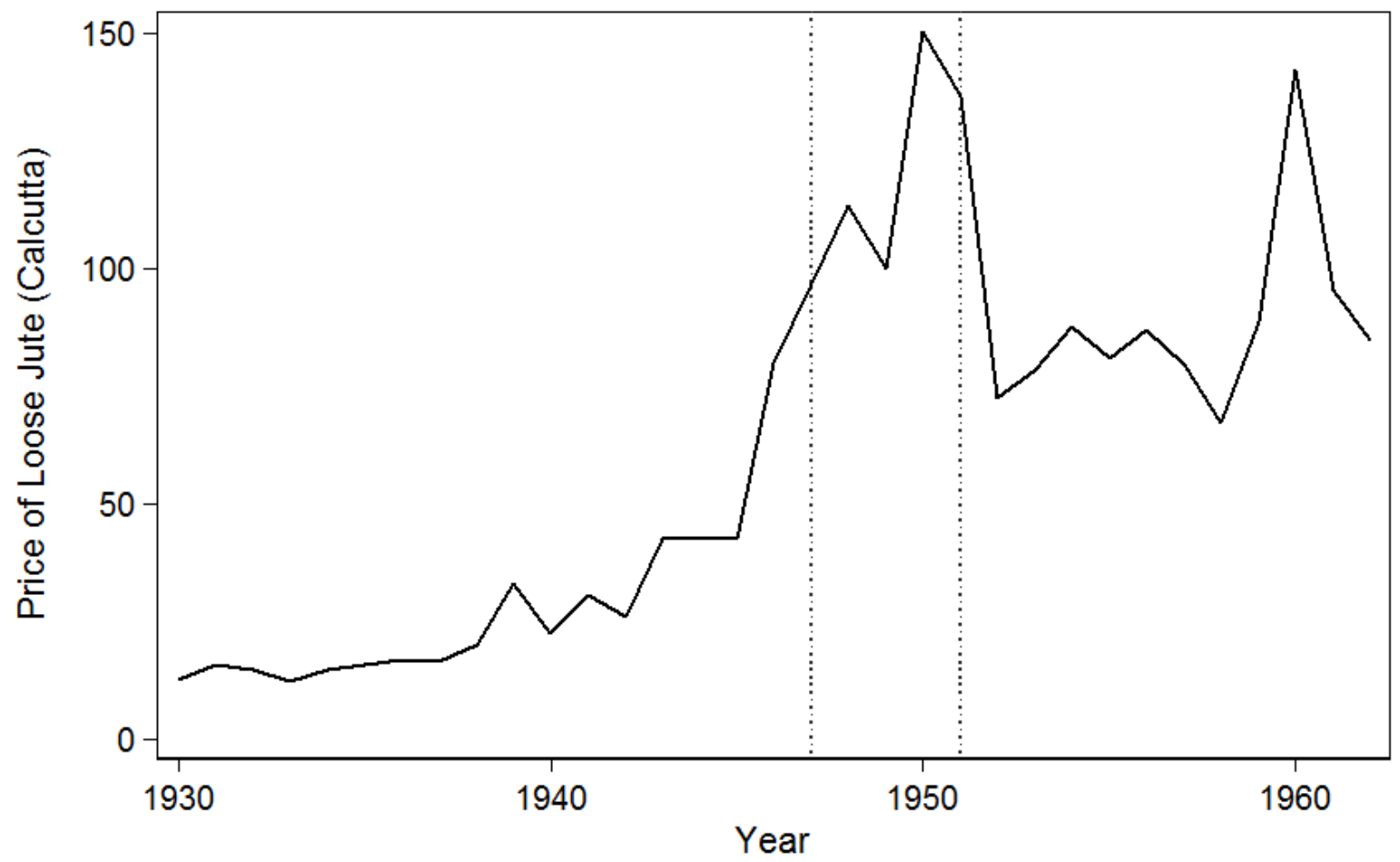

The price is in Rs.P. per $100 \mathrm{Kg}$. Data are taken from IJMA (1963). The beginning and end of partition are marked with vertical lines. 
Figure 2. Trend breaks in jute acreage and output
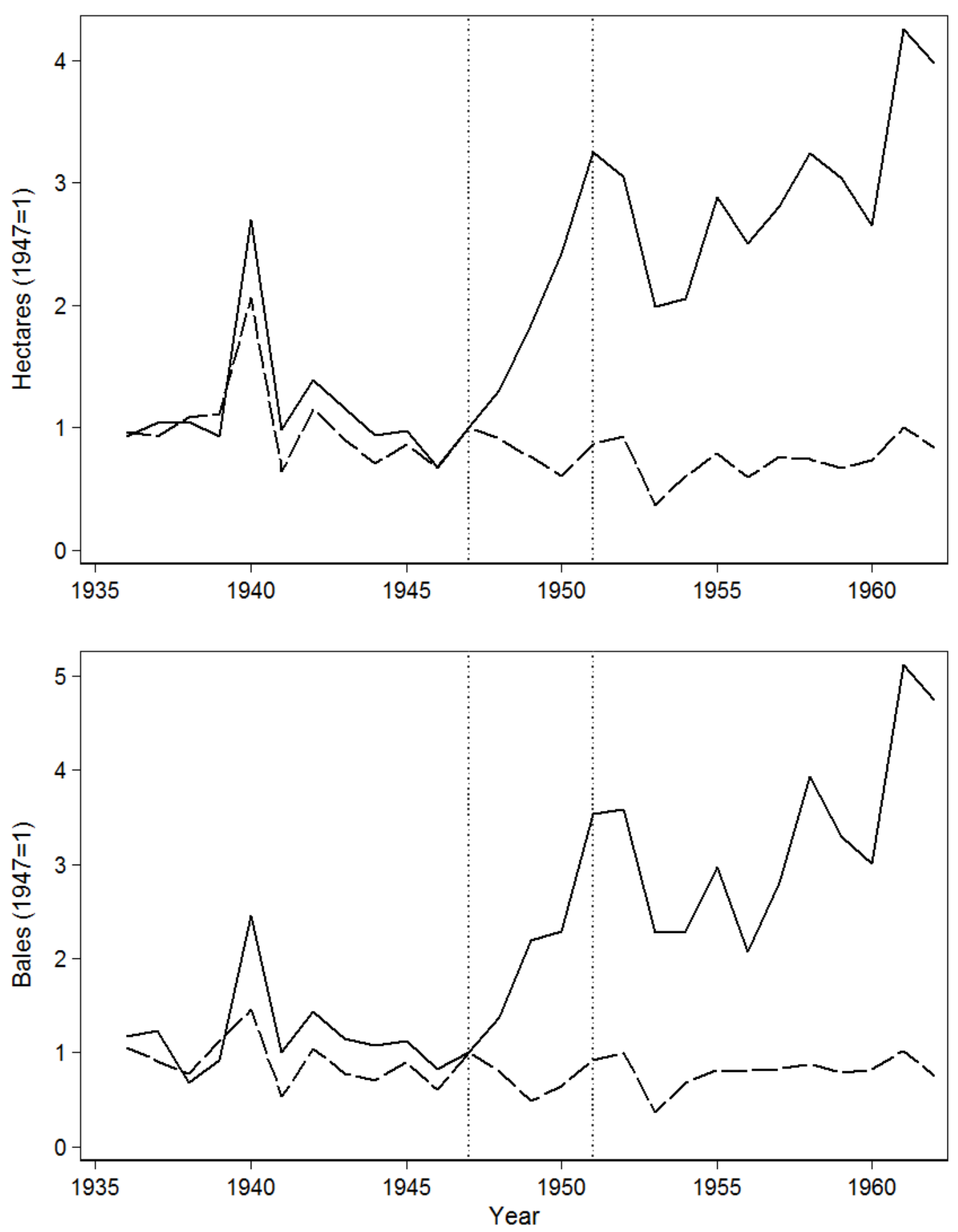

West Bengal is indicated with a solid line, East Pakistan with a dotted line. These Figures have no units, since they are indexed to their 1947 values for ease of comparison (production in East 
Pakistan was much larger than in West Bengal). Data are taken from IJMA (1963). The beginning and end of partition are marked with vertical lines.

Figure 3. Jute acres per capita, 1956

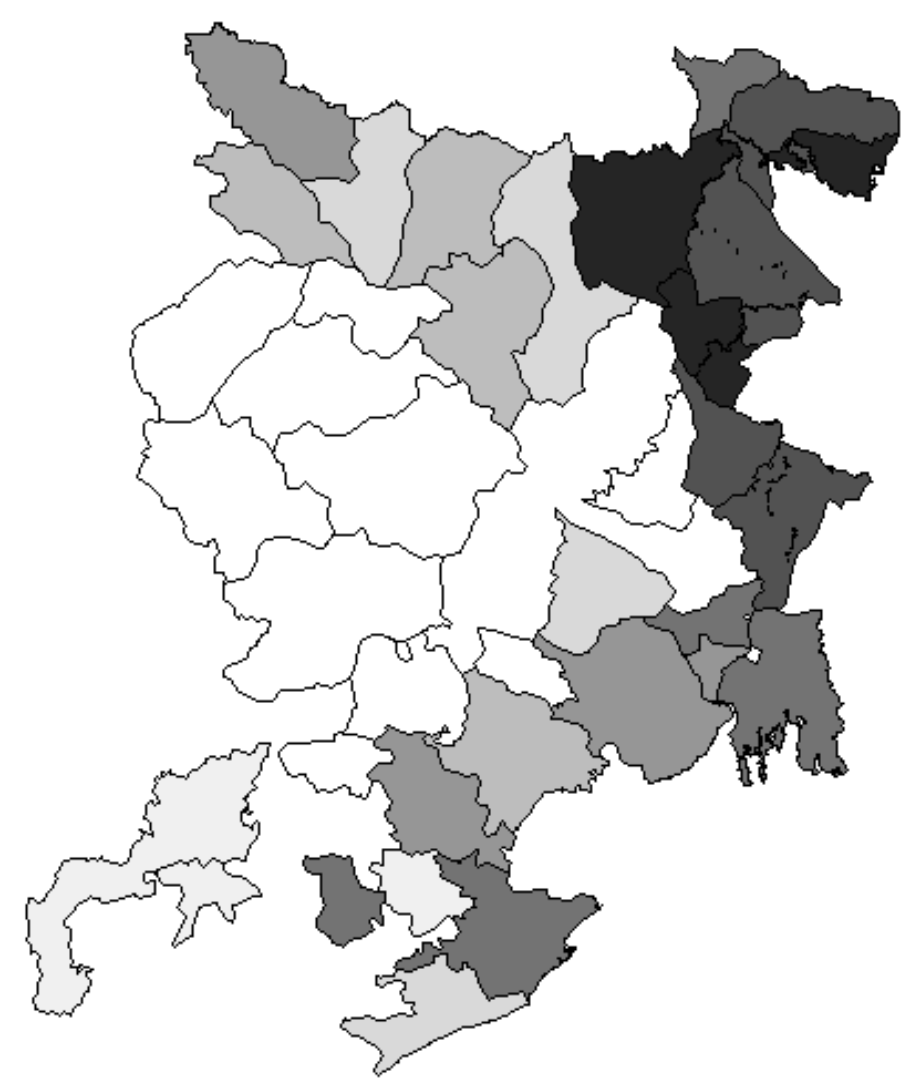

Darker colors indicate higher values. Districts with missing values not drawn. The variable range is given in Table 1. 
Figure 4. Sqrt. Of Migrant Share

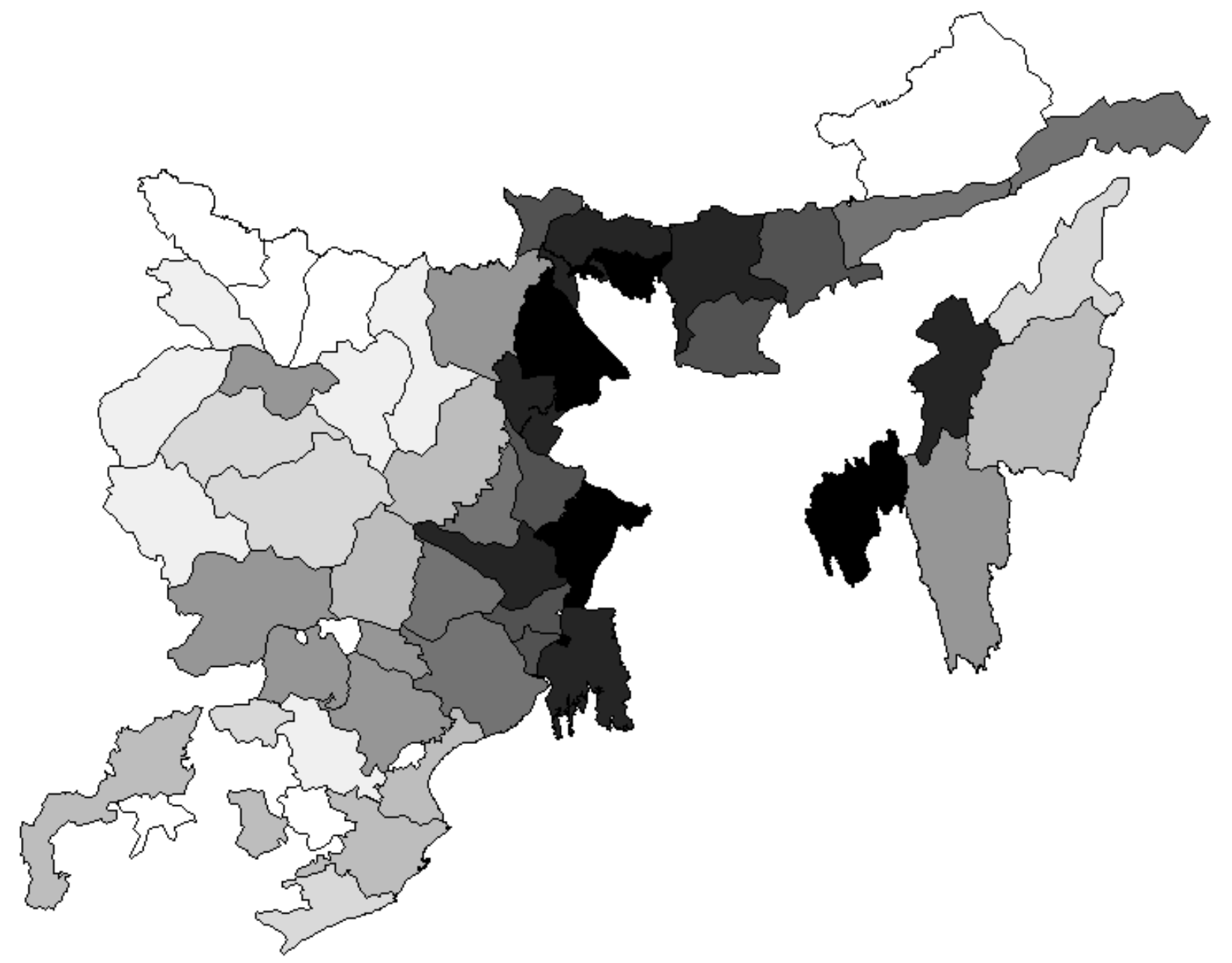

Darker colors indicate higher values. Districts with missing values not drawn. The variable range is given in Table 1. 
Figure 5. Log distance from border

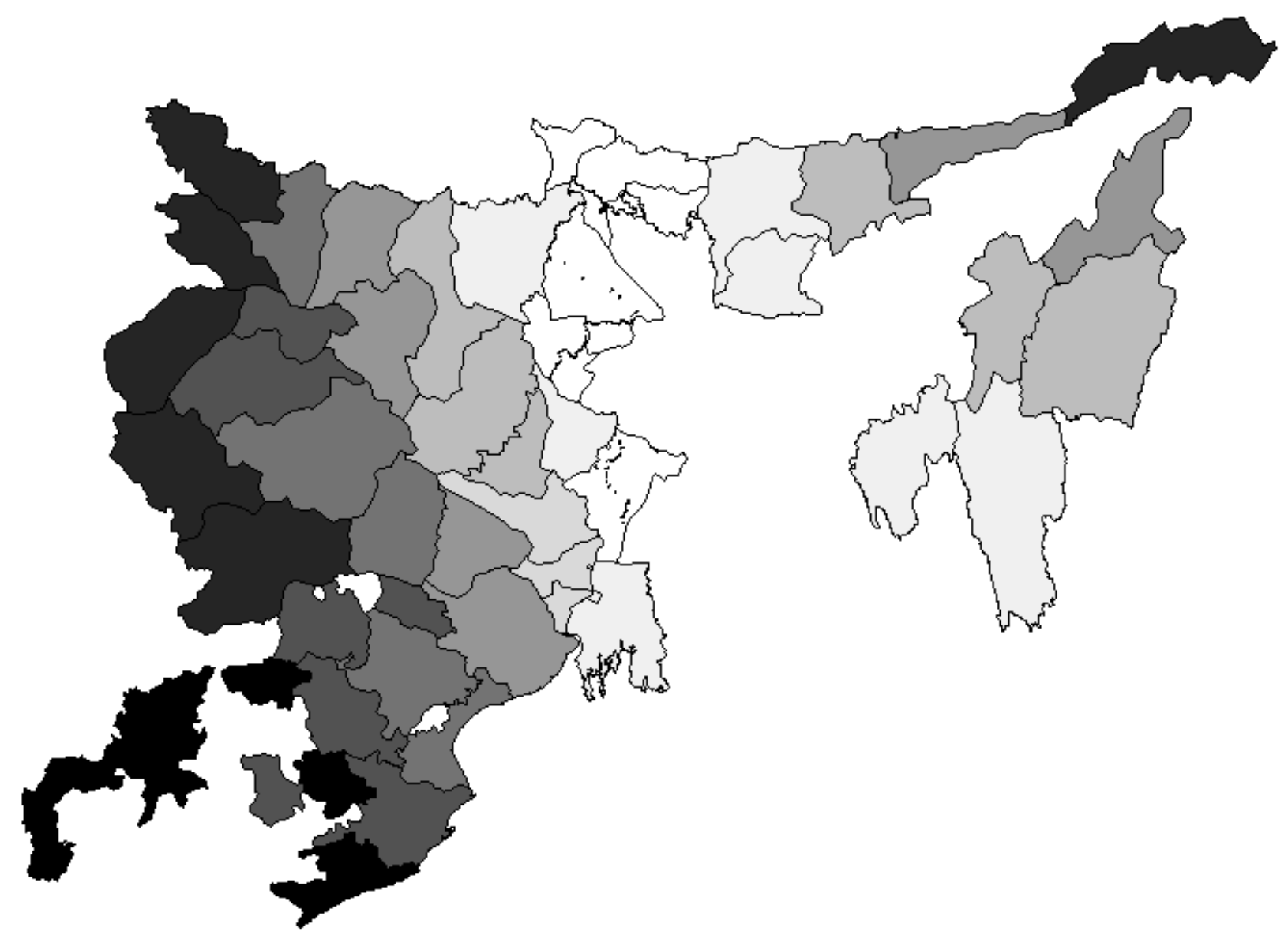

Darker colors indicate higher values. Districts with missing values not drawn. The variable range is given in Table 1 . 
Table 1. Summary statistics

\begin{tabular}{|l|c|c|c|c|c|}
\hline & Mean & Std. Dev. & Min & Max & N \\
\hline Jute Acres per Capita x 100, 1956 & 2.20 & 3.86 & 0 & 15.1 & 35 \\
\hline Jute Output per Capita x 100, 1956 & 192 & 334 & 0 & 1,369 & 35 \\
\hline Jute Yield x 100, 1956 & 63.2 & 42.3 & 0 & 129 & 35 \\
\hline Sqrt. of Migrant Share & 1.19 & 1.41 & 0.14 & 6.11 & 35 \\
\hline Log Distance from Border & 4.12 & 1.06 & 1.95 & 5.48 & 35 \\
\hline Jute Acres/100, 1931 & 87.3 & 220 & 0 & 1,200 & 35 \\
\hline Pop. Density/100, 1956 & 6.45 & 5.01 & 1.46 & 28.8 & 35 \\
\hline Big City Dummy & 0.057 & 0.24 & 0 & 1 & 35 \\
\hline Male Literacy, 1956 & 21.3 & 8.25 & 7.69 & 40.5 & 35 \\
\hline Minority Share, 1931 & 15.8 & 16.4 & 0.19 & 55.6 & 35 \\
\hline Nadia Dummy & 0.029 & 0.17 & 0 & 1 & 35 \\
\hline
\end{tabular}

Notes: Jute output is measures in thousands of tons. Yield is in tons per hectare. Distance from the border is measured in miles. Population density is per square kilometer. Data are taken from the 1931 and 1951 Censuses of India, the 1931 Agricultural Census and the World Bank Agricultural and Climate data set. 
Table 2. The impact of migrants on jute acreage

\begin{tabular}{|c|c|c|c|c|c|c|c|c|}
\hline & $(1)$ & $(2)$ & $(3)$ & $(4)$ & $(5)$ & $(6)$ & $(7)$ & $(8)$ \\
\hline & \multicolumn{8}{|c|}{ Dependent variable: Jute acres per capita X 100, 1956} \\
\hline & \multicolumn{4}{|c|}{ OLS } & \multicolumn{4}{|c|}{ IV } \\
\hline \multirow[t]{2}{*}{ Sqrt. of Migrant Share } & $1.61 * * *$ & $1.16^{* *}$ & 1.33 & 1.48 & $2.26 * * *$ & $1.30 * * *$ & $2.11^{* * *}$ & $2.20 * * *$ \\
\hline & $(0.43)$ & $(0.58)$ & $(0.87)$ & $(0.95)$ & $(0.58)$ & $(0.41)$ & $(0.66)$ & $(0.78)$ \\
\hline \multirow[t]{2}{*}{ Jute Acres/100, 1931} & & $0.01 * * *$ & $0.01 * * *$ & -0.01 & & $0.01 * * *$ & $0.01 * * *$ & -0.01 \\
\hline & & $(0.00)$ & $(0.00)$ & (0.01) & & $(0.00)$ & $(0.00)$ & $(0.01)$ \\
\hline \multirow[t]{2}{*}{ Pop. Density/100, 1956} & & $-0.10 * *$ & -0.06 & 0.26 & & $-0.09 *$ & -0.02 & $0.35 * *$ \\
\hline & & $(0.05)$ & $(0.05)$ & $(0.17)$ & & $(0.05)$ & $(0.05)$ & $(0.18)$ \\
\hline \multirow[t]{2}{*}{ Big City Dummy } & 2 & 1.07 & 0.52 & $-8.03 * * *$ & & 1.06 & -0.00 & $-9.33^{* * *}$ \\
\hline & & $(1.33)$ & (1.73) & $(3.04)$ & & (1.33) & (1.51) & $(3.05)$ \\
\hline \multirow[t]{2}{*}{ Male Literacy, 1956} & & -0.08 & -0.07 & 0.01 & & -0.09 & -0.08 & -0.00 \\
\hline & & $(0.06)$ & $(0.07)$ & $(0.05)$ & & $(0.07)$ & $(0.08)$ & $(0.05)$ \\
\hline \multirow[t]{2}{*}{ Minority Share, 1931} & & $0.10^{* * *}$ & $0.11 * * *$ & $0.13^{* * *}$ & & $0.09 * * *$ & $0.09 * * *$ & $0.10^{* *}$ \\
\hline & & $(0.02)$ & $(0.02)$ & $(0.04)$ & & $(0.02)$ & $(0.03)$ & $(0.05)$ \\
\hline \multirow[t]{2}{*}{ Nadia Dummy } & & $-7.17 * *$ & $-7.90 * *$ & $-6.10 *$ & & $-7.63 * * *$ & $-10.42 * * *$ & $-8.32 * * *$ \\
\hline & & $(2.81)$ & $(3.72)$ & (3.35) & & $(2.05)$ & $(2.68)$ & $(2.66)$ \\
\hline Observations & 35 & 35 & 35 & 35 & 35 & 35 & 35 & 35 \\
\hline Other 1931 Acreages & No & No & No & Yes & No & No & No & Yes \\
\hline State F.E. & No & No & Yes & Yes & No & No & Yes & Yes \\
\hline KP F Statistic & & & $\sqrt{V}$ & 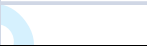 & 47.21 & 17.78 & 7.869 & 5.480 \\
\hline
\end{tabular}

Notes: ***Significant at $1 \%, * *$ Significant at $5 \%$, *Significant at $10 \%$. Robust z statistics in parentheses. All regressions include a constant. Data are taken from the 1931 and 1951 Censuses of India, the 1931 Agricultural Census and the World Bank Agricultural and Climate data set. 
Table 3. The impact of migrants on jute yields

\begin{tabular}{|c|c|c|c|c|c|c|c|c|}
\hline & $(1)$ & $(2)$ & (3) & $(4)$ & $(5)$ & $(6)$ & $(7)$ & $(8)$ \\
\hline & \multicolumn{8}{|c|}{ Dependent variable: Jute yield X 100, 1956} \\
\hline & \multicolumn{4}{|c|}{ OLS } & \multicolumn{4}{|c|}{ IV } \\
\hline \multirow[t]{2}{*}{ Sqrt. of Migrant Share } & $9.83 * * *$ & $22.29 * * *$ & 11.31 & $16.04 *$ & $14.97 * * *$ & $34.86^{* * *}$ & $42.26 * *$ & $42.10 * * *$ \\
\hline & (3.10) & (6.98) & $(7.94)$ & (8.29) & $(5.31)$ & $(11.74)$ & $(20.79)$ & $(15.89)$ \\
\hline \multirow[t]{2}{*}{ Jute Acres/100, 1931} & & $0.06 * * *$ & $0.07 * * *$ & $0.10^{*}$ & & $0.07 * * *$ & $0.07 * * *$ & 0.06 \\
\hline & & $(0.02)$ & $(0.01)$ & $(0.05)$ & & $(0.02)$ & $(0.02)$ & $(0.07)$ \\
\hline \multirow[t]{2}{*}{ Pop. Density/100, 1956} & & $5.51 * * *$ & $6.06 * * *$ & $10.47 * * *$ & & $6.25 * * *$ & $7.81 * * *$ & $13.68 * * *$ \\
\hline & & $(1.22)$ & $(1.57)$ & (3.44) & & $(1.50)$ & $(1.87)$ & (3.54) \\
\hline \multirow[t]{2}{*}{ Big City Dummy } & 2 & $-89.87 * * *$ & $-83.63 * * *$ & $-219.57 * * *$ & & $-90.08 * * *$ & $-104.17 * * *$ & *-267.01*** \\
\hline & & (21.09) & $(30.80)$ & $(68.88)$ & & $(25.50)$ & (38.72) & $(76.22)$ \\
\hline \multirow[t]{2}{*}{ Male Literacy, 1956} & & -0.91 & -1.35 & -1.20 & & -1.59 & $-1.68^{*}$ & -1.51 \\
\hline & & $(0.95)$ & $(0.85)$ & $(1.28)$ & & $(1.04)$ & $(0.96)$ & $(1.20)$ \\
\hline \multirow[t]{2}{*}{ Minority Share, 1931} & & $-1.49 * *$ & $-1.17^{*}$ & $-1.91^{* * *}$ & & $-2.22 * *$ & $-2.06 *$ & $-2.79 * * *$ \\
\hline & & $(0.72)$ & $(0.62)$ & $(0.54)$ & & (0.94) & (1.07) & $(0.80)$ \\
\hline \multirow[t]{3}{*}{ Nadia Dummy } & & $-55.98 * * *$ & -30.90 & -27.57 & & $-97.08 * *$ & $-129.75^{*}$ & $-107.82 * *$ \\
\hline & & $(19.79)$ & $(20.40)$ & $(26.56)$ & & $(40.20)$ & $(68.24)$ & $(49.48)$ \\
\hline & & & 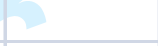 & & & & & \\
\hline Observations & 35 & 35 & 35 & 35 & 35 & 35 & 35 & 35 \\
\hline Other 1931 Acreages & No & No & No & Yes & No & No & No & Yes \\
\hline State F.E. & No & No & Yes & Yes & No & No & Yes & Yes \\
\hline KP F Statistic & & & $\sqrt{V}$ & & 47.21 & 17.78 & 7.869 & 5.480 \\
\hline
\end{tabular}

Notes: ***Significant at $1 \%, * *$ Significant at $5 \%$, *Significant at $10 \%$. Robust $\mathrm{z}$ statistics in parentheses. All regressions include a constant. Data are taken from the 1931 and 1951 Censuses of India, the 1931 Agricultural Census and the World Bank Agricultural and Climate data set. 
Table 4. The impact of migrants on native outcomes

\begin{tabular}{|c|c|c|c|c|c|c|c|c|}
\hline & $(1)$ & $(2)$ & (3) & (4) & $(5)$ & $(6)$ & (7) & (8) \\
\hline & \multicolumn{4}{|c|}{ OLS } & \multicolumn{4}{|c|}{ IV } \\
\hline & \multicolumn{8}{|c|}{ Dependent variable: Price of jute } \\
\hline \multirow[t]{2}{*}{ Sqrt. of Migrant Share } & $4.28 * * *$ & $9.54 * *$ & 1.45 & $-2.32 *$ & $5.82 * *$ & $13.16 * *$ & 11.42 & 1.91 \\
\hline & $(1.52)$ & (3.93) & $(1.79)$ & $(1.40)$ & $(2.43)$ & $(5.64)$ & $(7.12)$ & $(2.88)$ \\
\hline Observations & 35 & 35 & 35 & 35 & 35 & 35 & 35 & 35 \\
\hline \multirow[t]{2}{*}{ KP F Statistic } & P & & & & 47.21 & 17.78 & 7.869 & 5.480 \\
\hline & \multicolumn{8}{|c|}{ Dependent variable: Agricultural wage } \\
\hline \multirow[t]{2}{*}{ Sqrt. of Migrant Share } & $0.20 * * *$ & $0.19 * *$ & 0.05 & 0.07 & $0.28 * * *$ & $0.39 * * *$ & $0.28^{*}$ & 0.25 \\
\hline & $(0.06)$ & $(0.08)$ & $(0.09)$ & $(0.07)$ & $(0.08)$ & $(0.12)$ & $(0.17)$ & (0.19) \\
\hline Observations & 35 & 35 & 35 & 35 & 35 & 35 & 35 & 35 \\
\hline \multirow[t]{3}{*}{ KP F Statistic } & 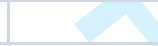 & 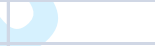 & & & 47.21 & 17.78 & 7.869 & 5.480 \\
\hline & & 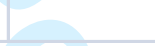 & & & & & & \\
\hline & \multicolumn{8}{|c|}{ Dependent variable: \% of native population in agriculture } \\
\hline \multirow[t]{2}{*}{ Sqrt. of Migrant Share } & $-6.21 * *$ & $-5.36^{*}$ & -2.08 & -3.60 & $-5.28 * *$ & -5.32 & 4.65 & 6.75 \\
\hline & $(2.60)$ & (2.95) & $(3.72)$ & (4.03) & $(2.36)$ & $(5.83)$ & $(10.51)$ & $(10.33)$ \\
\hline Observations & 51 & 51 & 51 & 51 & 50 & 50 & 50 & 50 \\
\hline \multirow[t]{3}{*}{ KP F Statistic } & & & 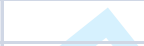 & & 55.90 & 24.03 & 5.086 & 2.987 \\
\hline & & & $1>$ & & & & & \\
\hline & \multicolumn{8}{|c|}{ Dependent variable: $\Delta \%$ of native population in agriculture, $1931-1956$} \\
\hline \multirow[t]{2}{*}{ Sqrt. of Migrant Share } & $-4.20 * * *$ & $-10.11 * * *$ & $-9.75 * *$ & $-10.23 * *$ & $-4.95 * *$ & $-13.20 * *$ & -14.32 & -18.88 \\
\hline & $(1.15)$ & $(2.95)$ & $(3.80)$ & $(4.05)$ & $(2.12)$ & $(5.92)$ & $(15.19)$ & $(16.74)$ \\
\hline Observations & 46 & 46 & 46 & 46 & 45 & 45 & 45 & 45 \\
\hline KP F Statistic & & & & & 39.70 & 17.29 & 2.598 & 0.936 \\
\hline Other Controls & No & Yes & Yes & Yes & No & Yes & Yes & Yes \\
\hline Other 1931 Acreages & No & No & No & Yes & No & No & No & Yes \\
\hline State F.E. & No & No & Yes & Yes & No & No & Yes & Yes \\
\hline
\end{tabular}

Notes: $* * *$ Significant at $1 \%, * *$ Significant at $5 \%, *$ Significant at $10 \%$. Robust $\mathrm{z}$ statistics in parentheses. All regressions include a constant. Data are taken from the 1931 and 1951 Censuses of India, the 1931 Agricultural Census and the World Bank Agricultural and Climate data set. 
Table 5. Placebos: The impact of migrants on other crops

\begin{tabular}{|c|c|c|c|c|c|c|c|}
\hline & (1) & $(2)$ & (3) & (4) & (5) & (6) & (7) \\
\hline & \multicolumn{4}{|c|}{ OLS } & \multicolumn{3}{|c|}{ IV } \\
\hline & \multicolumn{7}{|c|}{ Dependent variable: Acreage X 100, 1956} \\
\hline & Wheat & Rice & Sugar & Maize & G.nut & Barley & Tobacco \\
\hline \multirow[t]{2}{*}{ Sqrt. of Migrant Share } & -0.17 & -0.94 & -0.86 & 2.85 & -0.09 & $-1.26^{*}$ & 0.49 \\
\hline & $(0.86)$ & $(15.25)$ & $(0.57)$ & $(2.86)$ & $(0.07)$ & $(0.74)$ & $(0.39)$ \\
\hline & & & & & & & \\
\hline 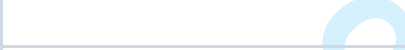 & Gram & Ragi & Sesame & Rape & Bajra & Cotton & Jowar \\
\hline \multirow[t]{5}{*}{ Sqrt. of Migrant Share } & -0.59 & -0.44 & $-1.13^{*}$ & $0.95^{* * *}$ & -0.01 & -0.03 & -0.01 \\
\hline & $(1.23)$ & $(0.37)$ & $(0.68)$ & $(0.26)$ & $(0.02)$ & $(0.04)$ & $(0.01)$ \\
\hline & 2 & & & & & & \\
\hline & \multicolumn{7}{|c|}{ Dependent variable: Yield X 100, 1956} \\
\hline & Wheat & Rice & Sugar & Maize & G.nut & Barley & Tobacco \\
\hline \multirow[t]{4}{*}{ Sqrt. of Migrant Share } & 9.42 & -2.61 & -3.48 & 6.98 & 3.68 & $-9.80^{*}$ & $14.36^{* * *}$ \\
\hline & (7.58) & $(3.02)$ & $(39.08)$ & $(6.53)$ & $(2.53)$ & $(5.91)$ & $(4.92)$ \\
\hline & & 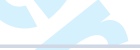 & & & & & \\
\hline & Gram & Ragi & Sesame & Rape & Bajra & Cotton & Jowar \\
\hline \multirow[t]{2}{*}{ Sqrt. of Migrant Share } & -5.76 & -6.70 & -0.61 & $-7.60 *$ & -2.69 & -0.12 & -5.53 \\
\hline & (10.69) & $(6.29)$ & $(1.46)$ & (4.19) & $(2.86)$ & $(0.79)$ & (3.62) \\
\hline
\end{tabular}

Notes: ***Significant at $1 \%, * *$ Significant at $5 \%, *$ Significant at $10 \%$. Robust $\mathrm{z}$ statistics in parentheses. All regressions include a constant. All regressions are IV with log distance from the border as the excluded instrument. All regressions include state fixed effects and the other controls included in Column (7) of Table 2. The number of observations is 35 and the Kleibergen-Paap F-Statistic is 7.869. Data are taken from the 1931 and 1951 Censuses of India, the 1931 Agricultural Census and the World Bank Agricultural and Climate data set. 


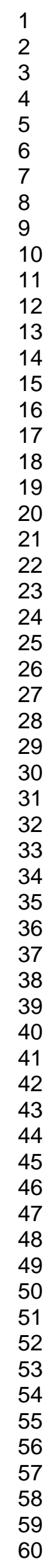

Table 6. Migration and demand shocks

URL: http://mc.manuscriptcentral.com/fjds 


\begin{tabular}{|c|c|c|c|c|c|c|c|c|}
\hline & (1) & (2) & (3) & (4) & (5) & (6) & (7) & (8) \\
\hline & \multicolumn{4}{|c|}{ OLS } & \multicolumn{4}{|c|}{ IV } \\
\hline & \multicolumn{8}{|c|}{ Dependent variable: Jute acres per capita X 100, 1956} \\
\hline \multirow[t]{2}{*}{ Sqrt. of Migrant Share } & $1.73 * * *$ & $1.09 *$ & 1.07 & 1.03 & $2.55^{* * *}$ & $1.24 * * *$ & $1.74 * * *$ & $2.10^{* * *}$ \\
\hline & $(0.42)$ & $(0.59)$ & $(0.84)$ & $(0.85)$ & $(0.64)$ & $(0.46)$ & $(0.54)$ & $(0.62)$ \\
\hline \multirow[t]{2}{*}{ Price of Jute } & $0.03^{*}$ & $0.02^{*}$ & 0.01 & -0.05 & $0.02^{*}$ & $0.02^{* *}$ & 0.01 & -0.03 \\
\hline & $(0.02)$ & $(0.01)$ & $(0.01)$ & $(0.04)$ & $(0.01)$ & $(0.01)$ & $(0.01)$ & $(0.03)$ \\
\hline \multirow[t]{4}{*}{ Distance from Calcutta } & $4.81 *$ & $3.95^{*}$ & 4.14 & $5.00^{*}$ & $6.99 * *$ & $3.94 *$ & 3.41 & 3.21 \\
\hline & $(2.50)$ & $(2.12)$ & $(2.60)$ & $(2.68)$ & $(3.44)$ & (2.11) & $(2.49)$ & $(2.80)$ \\
\hline & & & & & & & & \\
\hline & \multicolumn{8}{|c|}{ Dependent variable: Jute yield X 100, 1956} \\
\hline \multirow[t]{2}{*}{ Sqrt. of Migrant Share } & $6.60^{* *}$ & $14.54^{* *}$ & 5.90 & $11.94 *$ & $11.23 * *$ & $26.45^{* *}$ & $32.87^{*}$ & $34.21 * * *$ \\
\hline & $(3.23)$ & $(7.14)$ & (8.94) & $(6.94)$ & $(5.41)$ & $(10.99)$ & $(17.73)$ & $(12.23)$ \\
\hline \multirow[t]{2}{*}{ Price of Jute } & $1.15^{* * *}$ & $0.97 * * *$ & $0.56^{* *}$ & $1.66^{* * *}$ & $1.10^{* * *}$ & $0.81 * * *$ & $0.45^{*}$ & $1.97^{* * *}$ \\
\hline & $(0.13)$ & $(0.20)$ & $(0.25)$ & $(0.58)$ & $(0.14)$ & $(0.22)$ & $(0.27)$ & $(0.73)$ \\
\hline \multirow[t]{3}{*}{ Distance from Calcutta } & 31.01 & 48.78 & $77.35^{* * *}$ & $119.68^{* *}$ & 43.31 & 48.57 & 48.31 & 82.41 \\
\hline & $(30.40)$ & $(30.16)$ & $(28.75)$ & $(47.64)$ & $(32.60)$ & $(29.62)$ & $(36.69)$ & $(54.56)$ \\
\hline & \multicolumn{8}{|c|}{ Dependent variable: Jute acres per capita X 100, 1956} \\
\hline \multirow{2}{*}{ Sqrt. of Migrant Share } & $1.47^{* * *}$ & 0.92 & 1.20 & 1.21 & $2.16^{* * *}$ & $0.92 * *$ & $1.73 * * *$ & $1.61 * *$ \\
\hline & $(0.45)$ & $(0.59)$ & $(0.83)$ & $(0.87)$ & $(0.54)$ & $(0.39)$ & $(0.57)$ & $(0.69)$ \\
\hline \multirow[t]{2}{*}{ Jute Yield x 100, 1956} & 0.01 & $0.01 * *$ & $0.01 * *$ & $0.02 * *$ & 0.01 & $0.01^{* *}$ & $0.01^{* *}$ & 0.01 \\
\hline & $(0.01)$ & $(0.00)$ & $(0.00)$ & $(0.01)$ & $(0.01)$ & $(0.01)$ & $(0.00)$ & $(0.01)$ \\
\hline Other controls & No & Yes & Yes & Yes & No & Yes & Yes & Yes \\
\hline Other 1931 Acreages & No & No & No & Yes & No & No & No & Yes \\
\hline \multirow[t]{3}{*}{ State F.E. } & No & No & Yes & Yes & No & No & Yes & Yes \\
\hline & & & & & & & & \\
\hline & \multicolumn{8}{|c|}{ Dependent variable: Jute acres per capita X 100, 1956} \\
\hline \multirow[t]{2}{*}{ Sqrt. of Migrant Share } & & $1.03^{* *}$ & $0.77^{* *}$ & & $1.92^{* * *}$ & $1.96^{* *}$ & & \\
\hline & & $(0.41)$ & $(0.38)$ & & $(0.73)$ & $(0.79)$ & & \\
\hline \multirow[t]{2}{*}{ Jute Acres/100, 1931} & $0.01^{* * *}$ & $0.01^{* * *}$ & $0.01 * * *$ & & $0.01^{* * *}$ & $0.01^{* * *}$ & & \\
\hline & $(0.00)$ & $(0.00)$ & $(0.00)$ & & $(0.00)$ & $(0.00)$ & & \\
\hline \multirow[t]{2}{*}{ Big City Dummy } & -0.50 & -0.47 & 0.84 & & -0.44 & 0.24 & & \\
\hline & $(0.33)$ & $(0.31)$ & (0.68) & & $(0.37)$ & $(0.57)$ & & \\
\hline \multirow[t]{2}{*}{ Avg. Temp. 1956} & 1.07 & 1.00 & $2.67 * *$ & & 0.94 & $2.15^{*}$ & & \\
\hline & $(0.88)$ & $(0.73)$ & $(1.35)$ & & $(0.68)$ & $(1.28)$ & & \\
\hline \multirow[t]{2}{*}{ Avg. Rain 1956} & $0.04^{*}$ & 0.03 & $0.05^{*}$ & & 0.02 & 0.04 & & \\
\hline & $(0.02)$ & $(0.02)$ & $(0.03)$ & & $(0.02)$ & $(0.03)$ & & \\
\hline \multirow[t]{2}{*}{ Price of Jute } & -0.00 & 0.00 & $0.02 *$ & & 0.00 & $0.02 *$ & 2 & \\
\hline & $(0.01)$ & $(0.01)$ & $(0.01)$ & & $(0.01)$ & $(0.01)$ & 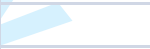 & \\
\hline \multirow[t]{2}{*}{ Distance from Calcutta } & -0.57 & 4.01 & $11.74^{* *}$ & & $7.95^{* *}$ & $10.34 * * *$ & & \\
\hline & $(2.88)$ & $(3.05)$ & $(4.62)$ & & $(3.56)$ & $(3.88)$ & & \\
\hline Observations & 34 & 34 & 34 & & 34 & 34 & & \\
\hline State F.E. & No & No & Yes & & No & Yes & & \\
\hline KP F Statistic & & & & & 17.56 & 10.93 & & \\
\hline
\end{tabular}

URL: http://mc.manuscriptcentral.com/fjds 
Notes: ***Significant at $1 \%, * *$ Significant at $5 \%, *$ Significant at $10 \%$. Robust $\mathrm{z}$ statistics in parentheses. All regressions include a constant. Data are taken from the 1931 and 1951 Censuses of India, the 1931 Agricultural Census and the World Bank Agricultural and Climate data set. 
Table 7. Other robustness checks

\begin{tabular}{|c|c|c|c|c|c|c|c|c|}
\hline & $(1)$ & $(2)$ & (3) & (4) & $(5)$ & $(6)$ & (7) & $(8)$ \\
\hline & \multicolumn{4}{|c|}{ OLS } & \multicolumn{4}{|c|}{ IV } \\
\hline & \multicolumn{8}{|c|}{ Dependent Variable: Jute Acres per Capita X 100 if Acres $>0$} \\
\hline \multirow[t]{2}{*}{ Sqrt. of Migrant Share } & $1.34 * * *$ & $1.27^{* *}$ & 0.70 & $0.86 *$ & $2.57 * * *$ & $3.48 * * *$ & $2.05^{* * *}$ & $2.36^{* * *}$ \\
\hline & $(0.34)$ & $(0.64)$ & $(0.54)$ & $(0.50)$ & $(0.70)$ & $(0.98)$ & $(0.77)$ & $(0.75)$ \\
\hline Observations & 70 & 70 & 70 & 70 & 70 & 70 & 70 & 70 \\
\hline \multirow[t]{3}{*}{ KP F Statistic } & P & & & & 35.40 & 14.78 & 17.07 & 10.74 \\
\hline & & & & & & & & \\
\hline & \multicolumn{8}{|c|}{ Dependent Variable: Imputed jute yield X 100, 1956} \\
\hline \multirow[t]{2}{*}{ Sqrt. of Migrant Share } & 2.74 & 6.47 & 1.71 & -4.03 & 4.22 & $12.33^{*}$ & 8.30 & 3.47 \\
\hline & $(1.84)$ & (4.29) & $(4.35)$ & (4.47) & (2.91) & (6.97) & $(8.59)$ & $(8.57)$ \\
\hline Observations & 35 & 35 & 35 & 35 & 35 & 35 & 35 & 35 \\
\hline \multirow[t]{3}{*}{ KP F Statistic } & 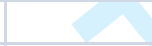 & (5) & & & 47.21 & 17.78 & 7.869 & 5.480 \\
\hline & & 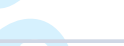 & & & & & & \\
\hline & \multicolumn{8}{|c|}{ Dependent Variable: Jute yield X 100, 1956, non-missing only } \\
\hline \multirow[t]{2}{*}{ Sqrt. of Migrant Share } & 2.52 & 9.59 & 4.02 & $-7.50 * * *$ & 3.95 & 16.81 & 15.23 & -0.89 \\
\hline & $(2.11)$ & (7.29) & $(6.18)$ & $(2.39)$ & (3.38) & $(10.46)$ & $(10.05)$ & $(4.45)$ \\
\hline Observations & 26 & 26 & 26 & 26 & 26 & 26 & 26 & 26 \\
\hline KP F Statistic & & & 2 & & 44.78 & 11.46 & 10.79 & 2.693 \\
\hline Other controls & No & Yes & Yes & Yes & No & Yes & Yes & Yes \\
\hline Other 1931 Acreages & No & No & No & Yes & No & No & No & Yes \\
\hline State F.E. & No & No & Yes & Yes & No & No & Yes & Yes \\
\hline
\end{tabular}

Notes: ***Significant at $1 \%$, **Significant at 5\%, *Significant at $10 \%$. Robust z statistics in parentheses. All regressions include a constant. Data are taken from the 1931 and 1951 Censuses of India, the 1931 Agricultural Census and the World Bank Agricultural and Climate data set. 
Table 8. First stage results

\begin{tabular}{|c|c|c|c|c|}
\hline & (1) & $(2)$ & (3) & $(4)$ \\
\hline & \multicolumn{4}{|c|}{ Dependent variable: Sqrt of migrant share } \\
\hline \multirow[t]{2}{*}{ Log Distance from Border } & $-1.16 * * *$ & $-0.98 * * *$ & $-0.87 * * *$ & $-1.03 * * *$ \\
\hline & $(0.16)$ & $(0.20)$ & $(0.26)$ & $(0.26)$ \\
\hline \multirow[t]{2}{*}{ Jute Acres/100, 1931} & & $-0.00 *$ & -0.00 & 0.00 \\
\hline & & $(0.00)$ & $(0.00)$ & $(0.00)$ \\
\hline \multirow[t]{2}{*}{ Pop. Density/100, 1956} & & $-0.04 * *$ & $-0.03 * *$ & -0.04 \\
\hline & & $(0.02)$ & $(0.02)$ & $(0.05)$ \\
\hline \multirow[t]{2}{*}{ Big City Dummy } & & 0.42 & 0.45 & 0.93 \\
\hline & 8 & $(0.40)$ & $(0.30)$ & $(1.00)$ \\
\hline \multirow[t]{2}{*}{ Male Literacy, 1956} & & $0.02 *$ & 0.02 & -0.00 \\
\hline & 1 & $(0.01)$ & (0.01) & $(0.01)$ \\
\hline \multirow[t]{2}{*}{ Minority Share, 1931} & 3 & 0.01 & 0.01 & 0.01 \\
\hline & 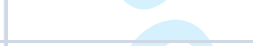 & $(0.01)$ & $(0.01)$ & $(0.01)$ \\
\hline \multirow[t]{2}{*}{ Nadia Dummy } & $1+$ & $2.91 * * *$ & $2.84 * * *$ & $2.38 * * *$ \\
\hline & $3 \sqrt{2}$ & $(0.27)$ & $(0.31)$ & $(0.26)$ \\
\hline Observations & 35 & 35 & 35 & 35 \\
\hline Other 1931 Acreages & No & No & No & Yes \\
\hline State F.E. & No & No & Yes & Yes \\
\hline
\end{tabular}

Notes: ***Significant at $1 \%, * *$ Significant at $5 \%, *$ Significant at $10 \%$. Robust $\mathrm{z}$ statistics in parentheses. All regressions include a constant. Data are taken from the 1931 and 1951 Censuses of India, the 1931 Agricultural Census and the World Bank Agricultural and Climate data set. 


\section{Dear Reviewer \#1:}

Thank you for your comments on our paper. We have done our best remedy the remaining issue you have identified. As we understand it, you are concerned that districts' innate suitability for jute was correlated with the post-partition increase in demand for jute, and that this increased demand attracted migrants towards districts where the post-partition increase in production would have been greatest even without them. We have five strategies for making the argument that the correlation between migrants and jute production is "supply driven," rather than "demand driven."

First, the main specification includes (and has always included) the acreage of jute in 1931. In so far as the post-partition increase in demand for jute was concentrated in those districts that are more suitable for jute cultivation, we have been using this variable to control for suitability the whole time.

Second, we have included the price of jute and distance from Calcutta as additional controls on the right hand side in Table 6. There was some confusion about this in the last report. Originally, we only did this with acreage as a dependent variable. The regressions in Table 6 that included yields as a dependent variable did not include these controls, and were rather alternative calculations of yields - different robustness checks. We have now split Table 6 into two separate tables (the new tables 6 and 7) for clarity. We have also replicated the analysis using yields as a dependent variable and including price and distance as additional controls. The effect of migrants on jute yields remains positive and significant.

Third, we argue that the "big city dummy" and distance from Calcutta should fully capture demand shocks, since all processing facilities were located in Calcutta. We have noted in the text of the paper that the overwhelming majority of jute mills in Bengal were located in that city (in section 5.2).

Fourth, we now use geographic features of the districts as indicators of their suitability for jute cultivation. We show in Table 6 that we can still find a relationship between jute and migration when we condition on all of our "demand-side" factors - lagged acreage, the big city dummy, average monthly temperature and rainfall in 1956 as recorded by the World Bank, the price of jute, and distance from Calcutta.

Fifth, we have included jute yields in 1956 as an additional right-hand side control variable when acres are the dependent variable. Yield is potentially endogenous, so it is not included as a control in the main specifications, but if the correlation between migrants and output can be fully explained by migrants moving into districts where the potential for output expansion was greatest, then this variable should make the effect of migration go away. It doesn't. While the OLS coefficients are no longer statistically significant, their magnitudes have not fallen by very much, suggesting this is simply multicollinearity. More importantly, the IV results remain positive and statistically significant.

Thank you again for your insightful comments. If there are remaining concerns we'd gladly try to account for them in another round of edits. 